\title{
High seroprevalence and associated factors for visceral leishmaniasis in dogs in a transmission area of Paraíba state, Northeastern Brazil
}

\author{
Alta soroprevalência e fatores associados da leishmaniose visceral canina em \\ área de transmissão do Estado da Paraíba, Nordeste do Brasil
}

\begin{abstract}
Maria das Graças da Silva Bernardino1; Débora Ferreira do Santos Angelo2; Raizza Barros Sousa Silva1;
Edijanio Galdino da Silva'; Laysa Freire Franco e Silva1; Antônio Fernando de Melo Vaz; Marcia Almeida de Melo';

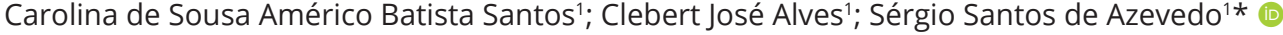

1 Programa de Pós-graduação em Ciência e Saúde Animal, Centro de Saúde e Tecnologia Rural, Universidade Federal de Campina Grande - UFCG, Patos, PB, Brasil

${ }^{2}$ Programa de Pós-graduação em Ciência Animal, Centro de Ciências Agrárias, Universidade Federal da Paraíba - UFPB, Areia, PB, Brasil
\end{abstract}

How to cite: Bernardino MGS, Angelo DFS, Silva RBS, Silva EG, Silva LFF, Vaz AFM, et al. High seroprevalence and associated factors for visceral leishmaniasis in dogs in a transmission area of Paraíba state, Northeastern Brazil. Braz J Vet Parasitol 2020; 29(2): e016919. http://doi.org/10.1590/S1984-29612020014

\begin{abstract}
Dogs have been implicated as main reservoirs for visceral leishmaniasis (VL) in urban areas. Therefore, studies on this species provide important data for public health. Thus, the objective of the present study was to ascertain the seroprevalence of canine $\mathrm{VL}(\mathrm{CVL})$ and the associated factors in the Brejo Paraibano microregion, northeastern Brazil. A total of 409 dogs were sampled from the eight municipalities of the microregion: Alagoa Grande, Alagoa Nova, Areia, Bananeiras, Borborema, Matinhas, Pilões and Serraria. The diagnosis of CVL was made using an enzyme-linked immunosorbent assay (ELISA S7 ${ }^{\circledR}$ ), through which the prevalence observed was $29.3 \%$. By robust Poisson regression analysis two factors were associated with seroprevalence: illiterate/incomplete elementary owner's education level (prevalence ratio $=1.57 ; 95 \% \mathrm{Cl}=1.05-2.34 ; \mathrm{p}$-value $=0.027$ ) and tick infestation (prevalence ratio $=1.82 ; 95 \% \mathrm{Cl}=1.27-2.61 ; p$-value $=0.001)$. It is concluded that the seroprevalence of CVL in the Brejo Paraibano microregion is high. The factors associated with seroprevalence indicated the importance to develop socioeducational actions on the population, and the finding that tick infestation was associated with seroprevalence shows that there is a need for investigation regarding the role of ticks in the epidemiology of CVL.
\end{abstract}

Keywords: Leishmania infantum, zoonosis, public health, epidemiology.

\begin{abstract}
Resumo
Os cães são apontados como principais reservatórios da leishmaniose visceral (LV) em áreas urbanas. Portanto, estudos com essa espécie fornecem dados importantes para a saúde pública. Assim, o objetivo do presente estudo foi determinar a soroprevalência da leishmaniose visceral canina (LVC) e os fatores associados na microrregião do Brejo Paraibano, Nordeste do Brasil. Foram amostrados 409 cães dos oito municípios da microrregião: Alagoa Grande, Alagoa Nova, Areia, Bananeiras, Borborema, Matinhas, Pilões e Serraria. O diagnóstico de LVC foi realizado com o ensaio imunoenzimático (kit ELISA S7 ${ }^{\circledR}$ ), no qual a prevalência observada foi de $29,3 \%$. Pela análise de regressão de Poisson robusta, dois fatores foram associados à soroprevalência: proprietário analfabeto ou com ensino fundamental incompleto (razão de prevalência = 1,57; IC 95\% =1,05-2,34; p-valor = 0,027) e infestação de carrapatos (razão de prevalência =1,82; IC 95\% =1,27-2,61; p-valor =0,001). Conclui-se que a soroprevalência da LVC na microrregião Brejo Paraibano é alta. Os fatores associados à soroprevalência indicaram a importância do desenvolvimento de ações socioeducativas na população, e a associação da infestação de carrapatos com a soroprevalência mostra que há necessidade de investigação sobre o papel dos carrapatos na epidemiologia da LVC.
\end{abstract}

Palavras-chave: Leishmania infantum, zoonose, saúde pública, epidemiologia. 


\section{Introduction}

Visceral leishmaniasis (VL) is an infectious disease that presents zoonotic characteristics and is caused by the protozoon Leishmania infantum (Kuhls et al., 2011). It is a systemic disease that usually presents chronically and, when untreated, it may evolve to death in over $90 \%$ of cases (Brasil, 2016).

Among the hosts susceptible to infection, domestic dogs (Canis familiaris) and humans stand out. Dogs have been implicated as the main reservoir in urban areas (Brasil, 2016). The fact that humans live together with domestic dogs in a close sentimental relationship may therefore have a series of implications for public health. Another important factor within the epidemiology of this disease is that approximately $40-60 \%$ of seropositive dogs present the asymptomatic form (Brasil, 2016), which favoring maintenance of reservoirs of this disease. In addition, no effective treatment that promotes elimination of parasites from infected hosts exists yet, thus making this disease difficult to control. Therefore, studies on dogs present predictive value for understanding the epidemiology of this disease in humans and other animal species (Boaz et al., 2018). It is essential to have the means to indicate disease prevalence and identify risk factors, in order to plan control and prevention strategies.

VL presents endemic characteristics in several countries, and Brazil has the second highest number of notifications (WHO, 2019). Among the cases confirmed in this country, over $40 \%$ occur in the northeastern region (Sinan, 2017). In the state of Paraíba, recent studies have indicated the importance of dogs as a reservoir for VL, with seroprevalence values that ranged from 2.8 to 38.6\% (Fernandes et al., 2016; Silva et al., 2016, 2017, 2018; Brasil et al., 2018). However, there is a lack of epidemiological studies on the population of dogs in the Brejo Paraibano microregion. This region presents specific characteristics that may influence occurrences of this disease, including the presence of remnants of the Atlantic Rainforest (Porto et al., 2004) and high rainfall (AESA, 2019). Therefore, the objective of the present study was to ascertain the seroprevalence of canine visceral leishmaniasis $(\mathrm{CVL})$ and the associated factors in dogs in the Brejo Paraibano microregion.

\section{Materials and Methods}

The present study was approved by the Research Ethics Committee of the Rural Healthcare and Technology Center of the Federal University of Campina Grande, under protocol no. 025/2017.

This study was conducted on dogs living in the urban area of the Brejo Paraibano ("Paraíba marshes") microregion, in the state of Paraíba, Northeastern Brazil, which consists of eight municipalities, namely: Alagoa Grande, Alagoa Nova, Areia, Bananeiras, Borborema, Matinhas, Pilões and Serraria. Its territorial area is $840,452 \mathrm{~km}^{2}$, with a population of 116,488 inhabitants (IBGE, 2010) and cumulative rainfall of 11,091.9 mm over the past 10 years (AESA, 2019). This microregion presents Atlantic Rainforest biomes that appear in high-altitude sectors, called high-altitude marshes (Porto et al., 2004).

In order to define the minimum number of animals to be sampled, a formula for simple random samples was used (Thrusfield, 2007), considering the following parameters: expected prevalence of $50 \%$ (sample maximization), confidence level of $95 \%(z=1.96)$ and statistical error of $5 \%$, which resulted in a minimum sample size of 384 dogs. In the end, 409 dogs older than three months of age, of both sexes and various breeds were used. The minimum number of dogs to be sampled in each municipality of the microregion was defined proportionally according to the number of inhabitants (Table 1).

The field work was conducted by a trained team through home visits to the residents of the microregion. The dogs' owners were given explanations about the objectives of the study and, after agreeing to participate, signed a free and informed consent statement. Sampling was done from May to October 2017. The animals were clinically examined and, concomitantly, a clinical examination form was filled in to record the findings from each individual. The animals' level of consciousness, posture, locomotion, nutritional state, rectal temperature, mucosal condition, state of hydration, lymph node condition and haircoat condition were assessed, and any complaints about clinical signs noticed by the owners were also recorded. From each animal a blood sample was collected, and after removal of the coagulum the serum was transferred to $1.5-\mathrm{mL}$ microtubes and stored at $-20^{\circ} \mathrm{C}$ until the time of the serological tests.

A questionnaire was applied to the owners to obtain data to be used in the analysis of factors associated with seroprevalence. The variables and respective categories considered in the questionnaire were: 
Table 1. Numbers of inhabitants, minimum number of dogs to be sampled, sampled dogs and positive animals in each municipality of the Brejo Paraibano microregion.

\begin{tabular}{|c|c|c|c|c|}
\hline Municipality & Inhabitants* & $\begin{array}{l}\text { Minimum number of } \\
\text { dogs to be sampled }\end{array}$ & Sampled dogs & Positive dogs (\%) \\
\hline Alagoa Grande & 28,479 & 94 & 101 & $43(42.6)$ \\
\hline Areia & 23,829 & 78 & 79 & $27(34.2)$ \\
\hline Bananeiras & 21,851 & 72 & 72 & $22(30.1)$ \\
\hline Alagoa Nova & 19,681 & 65 & 73 & $7(9.7)$ \\
\hline Serraria & 6,238 & 21 & 24 & $2(8.3)$ \\
\hline Pilões & 6,978 & 23 & 22 & $3(13.6)$ \\
\hline Borborema & 5,111 & 17 & 20 & $5(25.0)$ \\
\hline Matinhas & 4,321 & 14 & 18 & $11(61.1)$ \\
\hline Total & 116,488 & 384 & 409 & $120(29.3)$ \\
\hline
\end{tabular}

*Source: IBGE (2010). The variables selected (p-value $\leq 0.2$ ) in the univariable analysis were: owner's educational level, contact with small ruminants, destination of garbage, condition of housing, daily cleaning of the animals' environment, tick infestation, adequate ectoparasite control, and deworming (Table 2).

Table 2. Univariable analysis on the factors associated with seroprevalence for visceral leishmaniasis among dogs in the Brejo Paraibano microregion.

\begin{tabular}{|c|c|c|c|c|}
\hline Variable & Categories & $\begin{array}{l}\text { Total No. of } \\
\text { dogs }\end{array}$ & $\begin{array}{c}\text { Positive dogs } \\
\text { (\%) }\end{array}$ & p-value \\
\hline \multirow[t]{2}{*}{ Sex } & Female & 193 & $57(29.5)$ & \\
\hline & Male & 216 & $63(29.2)$ & 0.935 \\
\hline \multirow[t]{2}{*}{ Breed } & Without defined breed & 338 & $100(29.6)$ & \\
\hline & With defined breed & 71 & $20(28.2)$ & 0.812 \\
\hline \multirow[t]{3}{*}{ Age } & Up to 1 year & 88 & $21(23.9)$ & \\
\hline & $1-5$ years & 197 & $60(30.5)$ & \\
\hline & Over 5 years & 124 & $39(31.5)$ & 0.436 \\
\hline \multirow[t]{2}{*}{ Owner' educational level } & Illiterate/Incomplete elementary education & 288 & $96(33.3)$ & \\
\hline & Complete elementary education & 121 & $24(19.8)$ & $0.006^{*}$ \\
\hline \multirow[t]{3}{*}{ Family income } & Up to 1 minimum wage & 268 & $85(31.7)$ & \\
\hline & 1-2 minimum wages & 114 & $32(28.1)$ & \\
\hline & More than 2 minimum wages & 27 & $3(11.1)$ & $0,076^{*}$ \\
\hline \multirow[t]{2}{*}{ Contact with cats } & No & 257 & $70(27.2)$ & \\
\hline & Yes & 152 & $50(32.9)$ & 0.225 \\
\hline \multirow[t]{2}{*}{ Contact with small ruminants } & No & 381 & $112(29.4)$ & \\
\hline & Yes & 28 & $8(28.6)$ & 0.926 \\
\hline \multirow[t]{2}{*}{ Contact with cattle } & No & 398 & 119 (29.9) & \\
\hline & Yes & 11 & $1(9.1)$ & $0.135^{*}$ \\
\hline
\end{tabular}

*Variables selected for robust Poisson regression. The robust Poisson regression analysis confirmed that two factors were associated with seroprevalence (Table 3): illiterate/incomplete elementary owner's education level (prevalence ratio $=1.57 ; 95 \% \mathrm{Cl}=1.05-2.34 ; \mathrm{p}$-value $=0.027$ ) and tick infestation (prevalence ratio $=1.82 ; 95 \% \mathrm{Cl}=1.27-2.61 ; p$-value $=0.001$ ). The model presented good fit $($ Pearson Chi-square: value $=296.01$; degrees of freedom $-\mathrm{df}=396 ;$ value $/ \mathrm{df}=0.737$ ) and statistical significance (Omnibus test: likelihood ratio Chi-square $=27.13 ; \mathrm{df}=12 ; \mathrm{p}-\mathrm{value}=0.007$ ) 
Table 2. Continued...

\begin{tabular}{|c|c|c|c|c|}
\hline Variable & Categories & $\begin{array}{l}\text { Total No. of } \\
\text { dogs }\end{array}$ & $\begin{array}{c}\text { Positive dogs } \\
\text { (\%) }\end{array}$ & p-value \\
\hline \multirow[t]{2}{*}{ Contact with horses } & No & 393 & $119(30.3)$ & \\
\hline & Yes & 16 & $1(6.2)$ & $0.039 *$ \\
\hline \multirow[t]{2}{*}{ Presence of mosquitos } & No & 78 & $18(23.1)$ & \\
\hline & Yes & 331 & $102(30.8)$ & $0.177^{*}$ \\
\hline \multirow[t]{2}{*}{ Disposal of garbage } & Public collection & 390 & $115(29.5)$ & \\
\hline & Vacant lots or on the streets & 19 & $5(26.3)$ & 0.767 \\
\hline \multirow{2}{*}{$\begin{array}{l}\text { Type of water for human } \\
\text { consumption }\end{array}$} & Treated water & 215 & $63(29.3)$ & \\
\hline & Untreated water & 194 & $57(29.4)$ & 0.986 \\
\hline \multirow{2}{*}{$\begin{array}{l}\text { Does a veterinarian evaluate } \\
\text { your animals regularly? }\end{array}$} & Yes & 41 & $13(31.7)$ & \\
\hline & No & 368 & $107(29.1)$ & 0.726 \\
\hline \multirow[t]{3}{*}{ Condition of housing } & At home without access to streets & 65 & $10(15.4)$ & \\
\hline & At home with access to streets & 264 & $81(30.7)$ & \\
\hline & Free access to streets & 80 & $29(36.2)$ & $0.017^{*}$ \\
\hline \multirow{2}{*}{$\begin{array}{l}\text { Do you clean the animals' } \\
\text { environment daily? }\end{array}$} & Yes & 298 & $78(26.2)$ & \\
\hline & No & 111 & $42(37.8)$ & $0.021 *$ \\
\hline \multirow[t]{2}{*}{ Dog food } & Commercial & 26 & 7 (26.9) & \\
\hline & Commercial + homemade & 383 & $113(29.5)$ & 0.780 \\
\hline \multirow{2}{*}{$\begin{array}{l}\text { Type of water for dog } \\
\text { consumption }\end{array}$} & Treated & 199 & $49(24.6)$ & \\
\hline & Untreated & 210 & $71(33.8)$ & $0.041 *$ \\
\hline \multirow[t]{2}{*}{ Do you wash your animals? } & Yes & 358 & $104(29.1)$ & \\
\hline & No & 51 & $16(31.4)$ & 0.733 \\
\hline \multirow[t]{2}{*}{ Tick infestation } & No & 226 & $49(21.7)$ & \\
\hline & Yes & 183 & $71(38.8)$ & $<0.001 *$ \\
\hline \multirow[t]{2}{*}{ Adequate ectoparasite control } & Yes & 46 & $15(32.6)$ & \\
\hline & No & 363 & 105 (28.9) & 0.605 \\
\hline \multirow[t]{2}{*}{ Deworming } & Yes & 298 & $87(29.2)$ & \\
\hline & No & 111 & $33(29.7)$ & 0.916 \\
\hline \multirow[t]{2}{*}{ Animal with access to vacant lots } & No & 175 & $39(22.3)$ & \\
\hline & Yes & 234 & $81(34.6)$ & $0.007 *$ \\
\hline \multirow[t]{2}{*}{ Contact with wildlife } & No & 138 & $29(21.0)$ & \\
\hline & Yes & 271 & $91(33.6)$ & $0.008^{*}$ \\
\hline
\end{tabular}

*Variables selected for robust Poisson regression. The robust Poisson regression analysis confirmed that two factors were associated with seroprevalence (Table 3): illiterate/incomplete elementary owner's education level (prevalence ratio $=1.57 ; 95 \% \mathrm{Cl}=1.05-2.34 ; \mathrm{p}$-value $=0.027$ ) and tick infestation (prevalence ratio $=1.82 ; 95 \% \mathrm{Cl}=1.27-2.61 ; \mathrm{p}$-value $=0.001)$. The model presented good fit $($ Pearson Chi-square: value $=296.01$; degrees of freedom $-\mathrm{df}=396 ;$ value $/ \mathrm{df}=0.737$ ) and statistical significance (Omnibus test: likelihood ratio Chi-square $=27.13 ; \mathrm{df}=12 ; \mathrm{p}-\mathrm{value}=0.007$ ). 
(a) Information about the dog: sex (male, female), breed (without defined breed, with defined breed) and age (up to 1 year, between 1-5 years, over 5 years);

(b) Information about owner and residence: educational level (illiterate/incomplete primary education, completed elementary school), family income (up to 1 minimum wage, between 1-2 minimum wages, more than 2 minimum wages), type of water for consumption (treated, untreated), disposal of garbage (public collection, vacant lots or on the streets) and presence of mosquitoes (yes, no);

(c) Characteristics of animal husbandry: condition of housing (at home without access to streets, at home with access to streets, free access to streets), do you clean the animals' environment daily (yes, no), dog food (commercial, commercial + homemade), type of water for dog consumption (treated, untreated), do you wash your animals? (yes, no), tick infestation (yes, no), adequate ectoparasite control (yes, no), deworming (yes, no), does a veterinarian evaluate your animals regularly? (yes, no), animal with access to vacant lots (yes, no), contact with cats (yes, no), contact with small ruminants (yes, no), contact with cattle (yes, no), contact with horses (yes, no) and contact with wildlife (yes, no).

The serological diagnosis of VL in dogs was made using the enzyme-linked immunosorbent assay (ELISA S7 ${ }^{\circledR}$, Biogene Indústria e Comércio Ltda., Recife-PE, Brazil). This ELISA test is based on the recombinant carboxy-terminal fraction of the HSP70 protein. It presents mean sensitivity of $89 \%$, with the capacity to reach $96.4 \%$, and mean specificity of $94.3 \%$, with the capacity to reach $100 \%$. The test was conducted in accordance with the manufacturer's recommendations, in the Molecular Biology Laboratory of the Semiarid Region, at the Rural Healthcare and Technology Center of the Federal University of Campina Grande, Patos-PB.

The information obtained through the clinical examinations, epidemiological questionnaires, blood tests and serological tests were stored in a database that was created using the Microsoft Excel software. The clinical status of seropositive dogs was analyzed using the chi-square test for adherence, with a significance level of 5\%, through the BioEstat 5.3 statistical software (Ayres et al., 2007). To conduct the analysis of factors associated with seroprevalence, univariable analysis was initially performed, in which each independent variable underwent an association analysis in relation to the dependent variable (positivity in serological tests). Variables with p-value $\leq 0.2$ in the chi-square test (Zar, 1999) were selected for multivariable analysis using robust Poisson regression. Collinearity between independent variables was verified by a correlation analysis; for those variables with a strong collinearity (correlation coefficient $>0.9$ ), one of the two variables was excluded from the multiple analysis according to the biological plausibility (Dohoo et al., 2003). To assess how well the model fits the Person Chi-square was used, and the significance of the model was verified with Omnibus test. The significance level adopted in the multiple analysis was 5\%, and the software used was SPSS for Windows version 20.0.

\section{Results}

Out of the 409 samples analyzed, 120 were positive in the ELISA S7 ${ }^{\circledR}$ test, thus giving rise to seroprevalence of 29.3\%. The prevalence in the different municipalities ranged from 8.3 to $61.1 \%$, and positive animals were detected in all eight municipalities (Table 1 and Figure 1). Of the 120 seropositive animals only $15(12.5 \%)$ showed clinical signs suggestive of the disease $(P<0.001)$.

Table 3. Factors associated with seroprevalence for visceral leishmaniasis among dogs in the Brejo Paraibano microregion, determined using robust Poisson regression analysis.

\begin{tabular}{ccccccc}
\hline $\begin{array}{c}\text { Variable } \\
\text { category }\end{array}$ & $\begin{array}{c}\text { Coefficient } \\
\text { estimates }\end{array}$ & Standard error & $\begin{array}{c}\text { Wald Chi- } \\
\text { square }\end{array}$ & $\begin{array}{c}\text { Prevalence } \\
\text { ratio }\end{array}$ & 95\% Cl* & p-value \\
\hline $\begin{array}{c}\text { Illiterate/ } \\
\text { incomplete } \\
\text { elementary } \\
\text { owner's }\end{array}$ & 0.451 & 0.204 & 4.88 & 1.57 & $1.05 ; 2.34$ & 0.027 \\
$\begin{array}{c}\text { education level } \\
\text { Tick infestation }\end{array}$ & 0.6 & 0.183 & 10.8 & 1.82 & $1.27 ; 2.61$ & 0.001 \\
\hline
\end{tabular}

Goodness of fit: Pearson Chi-square value $=296.01$; degrees of freedom $=396$; value/df $=0.737$. ${ }^{*}$ Confidence interval of $95 \%$ for prevalence ratio. 


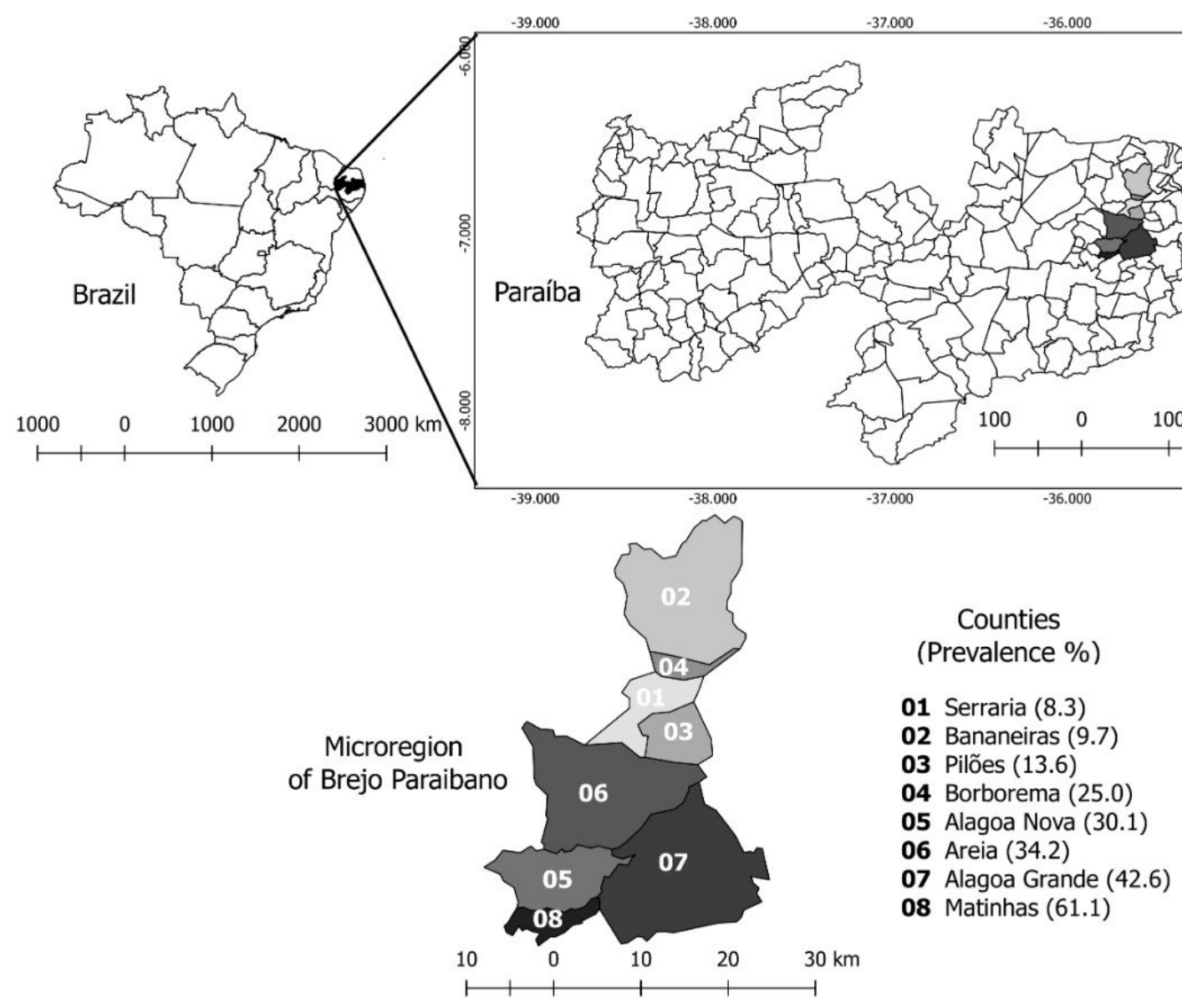

Figure 1. Geographic representation of the municipalities of Brejo Paraibano microregion, Brazil, and the seroprevalences for visceral leishmaniasis in dogs between May and October 2017.

\section{Discussion}

This was the first survey showing occurrences of visceral leishmaniasis among dogs in the Brejo Paraibano microregion and, depending on the municipality, the prevalence of this disease could reach over $60 \%$. This disparity highlights the importance of conducting epidemiological investigations in different regions of Brazil, in order to determine the areas that are at higher risk of presenting cases of visceral leishmaniasis among dogs and humans.

Most of the seropositive dogs were asymptomatic, which reinforce that this disease is difficult to diagnose clinically, and corroborate the epidemiological characteristics already reported for this disease, which included a high proportion of asymptomatic seropositive animals (Brasil, 2016). Therefore, the use of a highly sensitive diagnostic technique to detect animals in the early stages of the disease is extremely important from an epidemiological point of view, as asymptomatic dogs may be acting as silent reservoirs in the urban environment.

The seroprevalence found in this study was considered to be high compared with other studies conducted in the state of Paraíba using the ELISA S7 ${ }^{\circledR}$ as confirmatory test. Fernandes et al. (2016) conducted a study in urban centers of Paraíba (João Pessoa, Patos, Sousa, Campina Grande and Cajazeiras) and found prevalence of 7.8\%, i.e., 3.7 times lower than what was observed in the present study. This may have been related to the fact that larger municipalities have higher socioeconomic condition, which positively influences animal basic care and is reflected in the prevalence of diseases. Brasil et al. (2018) conducted a survey with dogs attended at veterinary clinics in the city of João Pessoa and found a prevalence of $2.8 \%$, a value that is 10.4 lower than what was observed in the present study, and this may be related to the higher purchasing power of tutors who attend private clinics, positively influencing the basic care of animals and the occurrence of diseases.

In another study conducted in this state, encompassing the municipalities of Cajazeiras, Sousa, Patos, and Uiraúna, also using ELISA S7 ${ }^{\circledR}$ as diagnostic test, a prevalence of $12.9 \%$ was observed (Silva et al., 2018). These differences can be attributed to the regional particularities of each locality, including the fact that these places 
are in different biomes. In those studies, the predominant biome was the caatinga, whereas the Brejo Paraibano microregion studied here presents remnants of the Atlantic Rainforest, which may have given rise to higher occurrence of the vector. These data corroborate the findings of Barbosa et al. (2010), who stated that localities closer to forests have 3.4 to 12 times greater chances of presenting animals that are seropositive for Leishmania spp.

We decided to use ELISA S7 ${ }^{\circledR}$ as diagnostic test because it is licensed for the diagnosis of CVL by the Brazilian Ministry of Agriculture, Livestock and Supply and is increasingly being used by researchers with purpose of detecting CVL seropositive animals (Figueiredo et al., 2014; Fernandes et al., 2016; Silva et al., 2017; Silva et al., 2018). Among the peculiarities of this test is the fact that it is highly specific, drastically reducing the cross-reactions that occur in tests that are based on whole antigen and require other complementary tests (Fernandes et al., 2016; Brasil et al., 2018). In addition, ELISA S7 ${ }^{\circledR}$ allows detection of antibodies at the earliest stage of infection, increasing the sensitivity to detect asymptomatic animals.

It is also noteworthy that currently the protocol recommended by the Ministry of Health for the diagnosis of CVL is through the use of the DPP ${ }^{\circledR}$ Rapid Immunochromatographic Test (Dual Path Platform - Biomanguinhos/FIOCRUZ) as screening and the ELISA (Kit EIE - CVL - Biomanguinhos/FIOCRUZ) as confirmatory (Brasil, 2011). However, although DPP ${ }^{\circledR}$ has good applicability for use in the field, as it is a fast and easily performed technique, it tends to present low sensitivity in detecting asymptomatic animals (Grimaldi et al., 2012). In addition, the ELISA (EIE kit - CVL) recommended as confirmatory test still uses the whole antigen, unlike ELISA S7 ${ }^{\circledR}$, which has a highly specific recombinant protein for the diagnosis of LVC as its antigen. Albuquerque (2006) found higher specificity of ELISA S7 ${ }^{\circledR}(89.4 \%)$ when compared to ELISA-EIE (85.6\%) for the diagnosis of CVL, however, ELISA S7 ${ }^{\circledR}$ had lower sensitivity (41.4\%) when compared to ELISA-EIE (65.8\%), which may be related to the infection phase of the dog population sampled in this study that included only symptomatic dogs, since ELISA S7 ${ }^{\circledR}$ has better sensitivity in detecting positive dogs at the onset of infection. Nóbrega (2014) reported better performance of ELISA S7 ${ }^{\circledR}$ when compared to DPP ${ }^{\circledast}$, both in sensitivity and specificity; among asymptomatic dogs DPP ${ }^{\circledR}$ presented $61 \%$ sensitivity and $86 \%$ specificity and ELISA S7 ${ }^{\circledR}$ presented $74 \%$ and $93 \%$, respectively.

The owner' educational level was associated with seroprevalence for $C V L$, such that dogs belonging to owners who were illiterate or incomplete elementary educational level presented prevalence that was 0.57 times greater than dogs whose owners had complete elementary education. This may have been a reflection from lack of knowledge regarding this disease and the type of care that is required for its prevention. This result corroborates what was reported by Coura-Vital et al. (2011), who identified lack of knowledge regarding the forms of transmission of VL as risk factor.

Dogs that presented tick infestation had prevalence that was 0.82 times greater than dogs without tick infestation, which may be related to failures in the primary care of these animals by the owners, predisposing the dogs to several diseases (Aktas et al., 2015) that can cause debilitation of the immune system. On the other hand, some studies had already shown the presence of Leishmania spp. in ticks found on dogs that were infected with VL (Coutinho et al., 2005; Campos \& Costa, 2014). In addition, oral transmission was shown to occur among hamsters after ingestion of infected ticks (Coutinho et al., 2005). Moreover, presence of promastigote forms of Leishmania spp. was observed recently in Rhipicephalus sanguineus (Viol et al., 2016). Another important factor is that the dendritic cells found in lymphoid tissues of the intestinal mucosa are able to expand their cytoplasmic extensions into the intestinal lumen and capture antigens (Tizard, 2014). This makes oral transmission possible if animals ingest ticks infected with Leishmania spp. In addition, the fact that ticks transmit several diseases, including potentially fatal ones, may also be a predisposing factor for transmission of VL because of debilitation of the immune system. Ineffective ectoparasite control was also observed to be a risk factor for CVL, and this serves to alert to the need for owners to use adequate protocols for tick control among their pets, since it is not yet clear whether ixodid ticks are also part of the epidemiology of VL.

\section{Conclusions}

It is concluded that the seroprevalence of visceral leishmaniasis among dogs in the Brejo Paraibano microregion is high. This is noteworthy because this region presents specific characteristics that may influence the occurrence of the disease, including the presence of remnants of the Atlantic Rainforest and high rainfall. The factors associated with seroprevalence indicated that there is a need to develop socioeducational actions on the population, with emphasis on knowledge about the epidemiology, and ways of preventing and controlling the disease. In addition, the finding that tick infestation was associated with seroprevalence shows that there is a need for deeper investigation regarding the role of ixodid ticks in the epidemiological cycle of VL. 


\section{References}

Agência Executiva de Gestão das Águas - AESA. Meteorologia - chuvas [online]. João Pessoa: AESA; 2019 [cited 2019 Fev 10]. Available from: http://www.aesa.pb.gov.br/aesa-website/meteorologia-chuvas/?formdate=2019-02-10\&produto=microrregiao \&periodo=personalizado

Aktas M, Özübek S, Altay K, Ipek NDS, Balkaya I, Utuk AE, et al. Molecular detection of tick-borne rickettsial and protozoan pathogens in domestic dogs from Turkey. Aktas et al. Parasit Vectors 2015; 8(1): 157. http://dx.doi.org/10.1186/s13071-0150763-z. PMid:25889911.

Albuquerque AR. Aspectos epidemiológicos, clínicos e de diagnóstico em cães (Canis familiares) (Linnaeus, 1758) naturalmente infectados por Leishmania (Leishmania) chagasi (Cunha \& Chagas, 1937) [dissertação]. Recife: Universidade Federal Rural de Pernambuco; 2006.

Ayres M, Ayres M Jr, Ayres DL, Santos AS. Bioestat 5.0 - Aplicações estatísticas nas áreas das ciências biomédicas. Belém: Sociedad Civil Mamirauá; 2007.

Barbosa DS, Rocha AL, Santana AA, Souza CSF, Dias RA, Costa-júnior LM, et al. Soroprevalência e variáveis epidemiológicas associadas à leishmaniose visceral canina em área endêmica no município de São Luís, Maranhão, Brasil. Cienc Anim Bras 2010; 11(3): 653-659. http://dx.doi.org/10.5216/cab.v11i3.5933.

Boaz R, Corberán-Vallet A, Lawson A, Ferreira Lima FE Jr, Donato LE, Alves RV, et al. Integration of animal health and public health surveillance sources to exhaustively inform the risk of zoonosis: an application to visceral leishmaniasis data in Brazil. Spat Spatio-Temporal Epidemiol 2018; 29: 177-185. http://dx.doi.org/10.1016/j.sste.2018.09.001. PMid:31128627.

Brasil AWL, Machado DMR, Silva MARX, Barrosa NC, Silva RBS, Melo MA, et al. Prevalence and risk factors associated with Leishmania spp. and Trypanosoma cruzi infections in dogs presented at veterinary clinics in João Pessoa, Paraíba state, northeastern Brazil. Semina: Ciênc Agrár 2018; 39(5): 2293-2300. http://dx.doi.org/10.5433/1679-0359.2018v39n5p2293.

Brasil. Ministério da Saúde. Secretaria de Vigilância em Saúde. Esclarecimentos sobre substituição do protocolo diagnóstico da leishmaniose visceral canina (LVC) [online]. Brasília: Ministério da Saúde; 2011 (Nota Técnica Conjunta; n 1) [cited 2019 Mar 26]. Available from: http://www.sgc.goias.gov.br/upload/arquivos/2012-05/nota-tecnica-no.-1-2011_cglab_cgdt1_Ivc.pdf

Brasil. Guia de Vigilância em Saúde [online]. Brasília: Ministério da Saúde; 2016 [cited 2019 Mar 26]. Available from: http:// portalarquivos2.saude.gov.br/images/pdf/2016/novembro/18/Guia-LV-2016.pdf

Campos JHF, Costa FAL. Participation of ticks in the infectious cycle of canine visceral leishmaniasis, in Teresina, Piauí, Brazil. Rev Inst Med Trop São Paulo 2014; 56(4): 297-300. http://dx.doi.org/10.1590/S0036-46652014000400005. PMid:25076429.

Coura-Vital W, Marques MJ, Veloso VM, Roatt BM, Aguiar-Soares RD, Reis LE, et al. Prevalence and factors associated with Leishmania infantum infection of dogs from an urban area of Brazil as identified by molecular methods. PLoS Neg/ Trop Dis 2011; 5(8): e1291. http://dx.doi.org/10.1371/journal.pntd.0001291. PMid:21858243.

Coutinho MTZ, Bueno LL, Sterzik A, Fujiwara RT, Botelho JR, De Maria M, et al. Participation of Rhipicephalus sanguineus (Acari: Ixodidae) in the epidemiology of canine visceral leishmaniasis. Vet Parasito/ 2005; 128(1-2): 149-155. http://dx.doi.org/10.1016/j. vetpar.2004.11.011. PMid:15725545.

Dohoo IR, Martin W, Stryhn H. Veterinary epidemiologic research. Charlottetown: Atlantic Veterinary College; 2003.

Fernandes ARF, Pimenta CLRM, Vidal IF, Oliveira GC, Sartori RS, Araújo RB, et al. Risk factors associated with seropositivity for Leishmania spp. and Trypanosoma cruzi in dogs in the state of Paraiba, Brazil. Rev Bras Parasitol Vet 2016; 25(1): 90-98. http:// dx.doi.org/10.1590/S1984-29612016010. PMid:26982555.

Figueiredo MJFM, Souza NF, Figueiredo HF, Meneses AMC, Silva E Fo, Nascimento GG. Fatores de risco e classificação clínica associados à soropositividade para Leishmaniose visceral canina. Cienc Anim Bras 2014; 15(1): 102-106. http://dx.doi.org/10.5216/ cab.v15i1.25097.

Grimaldi G Jr, Teva A, Ferreira AL, Santos CB, Pinto I, de-Azevedo CT, et al. Evaluation of a novel chromatographic immunoassay based on Dual-Path Platform technology (DPP ${ }^{\circledR}$ CVL rapid test) for the serodiagnosis of canine visceral leishmaniasis. Trans $R$ Soc Trop Med Hyg 2012; 106(1): 54-59. http://dx.doi.org/10.1016/j.trstmh.2011.10.001. PMid:22137538.

Instituto Brasileiro de Geografia e Estatística - IBGE. Brasil/Paraíba [online]. Brasília: IBGE; 2010 [cited 2019 Jan 30]. Available from: https://cidades.ibge.gov.br/brasil/pb/panorama

Kuhls K, Alam MZ, Cupolillo E, Ferreira GEM, Mauricio IL, Oddone R, et al. Comparative microsatellite typing of new world Leishmania infantum reveals low heterogeneity among populations and its recent old world origin. PLoS Neg/ Trop Dis 2011; 5(6): e1155. http://dx.doi.org/10.1371/journal.pntd.0001155. PMid:21666787.

Nóbrega GD. Comparação entre métodos recombinantes e PCR em tempo real no diagnóstico da leishmaniose visceral canina [dissertação]. Recife: Universidade Federal de Pernambuco; 2014.

Porto KC, Cabral JJP, Tabarelli M. Brejos de altitude em Pernambuco e Paraíba: história natural, ecologia e conservação [online]. Brasília: Ministério do Meio Ambiente; 2004 (Biodiversidade; vol. 9) [cited 2019 Mar 26]. Available from: http://www.terrabrasilis. org.br/ecotecadigital/pdf/brejos-de-altitude-em-pernambuco-e-paraiba-.pdf 
Silva JD, Melo DHM, Costa JAG, Costa DF, Silva RBS, Melo MA, et al. Leishmaniose visceral em cães de assentamentos rurais. Pesq Vet Bras 2017; 37(11): 1292-1298. http://dx.doi.org/10.1590/s0100-736x2017001100016.

Silva RBS, Mendes RS, Santana VL, Souza HC, Ramos CPS, Souza AP, et al. Aspectos epidemiológicos da Leishmaniose Visceral Canina na zona rural do semiárido paraibano e análise de técnicas de diagnóstico. Pesq Vet Bras 2016; 36(7): 625-629. http:// dx.doi.org/10.1590/S0100-736X2016000700011.

Silva RBS, Porto ML, Barbosa WO, Souza HC, Marques NFSP, Azevedo SS, et al. Seroprevalence and risk factors associated with canine visceral leishmaniasis in the State of Paraíba, Brazil. Rev Soc Bras Med Trop 2018; 51(5): 683-688. http://dx.doi. org/10.1590/0037-8682-0429-2017. PMid:30304279.

Sistema de Informação de Agravos de Notificação - SINAN. Dados epidemiológicos Sinan: doenças e agravos de notificação - de 2007 em diante [online]. Brasília: SINAN; 2017 [cited 2019 Mar 6]. Available from: http://portalsinan.saude.gov.br/dadosepidemiologicos-sinan

Thrusfield M. Veterinary epidemiology. Oxford: Wiley Blackwell; 2007.

Tizard I. Imunologia veterinária. 9. ed. Rio de Janeiro: Elsevier; 2014.

Viol MA, Guerrero FD, Oliveira BCM, Aquino MCC, Loiola SH, Melo GD, et al. Identification of Leishmania spp. promastigotes in the intestines, ovaries, and salivary glands of Rhipicephalus sanguineus actively infesting dogs. Parasitol Res 2016; 115(9): 34793484. http://dx.doi.org/10.1007/s00436-016-5111-5. PMid:27169724.

World Health Organization - WHO. Leishmaniasis: background information [online]. Geneva: WHO; 2019 [cited 2019 Mar 26]. Available from: https://www.who.int/leishmaniasis/disease/en/

Zar JH. Biostatistical analysis. 4th ed. New Jersey: Prentice-Hall; 1999. 